\title{
From Doing to Performing Phenomenology: Implications and Possibilities
}

\section{Sigrid Merx}

\section{Foundations of Science}

The official Journal of the Association for Foundations of Science, Language and Cognition

ISSN 1233-1821

Found Sci

DOI 10.1007/s10699-011-9262-7

\section{FOUNDATIONS}

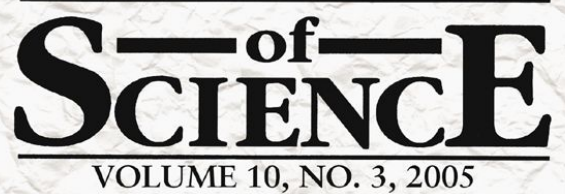


Your article is protected by copyright and all rights are held exclusively by Springer Science+Business Media B.V.. This e-offprint is for personal use only and shall not be selfarchived in electronic repositories. If you wish to self-archive your work, please use the accepted author's version for posting to your own website or your institution's repository. You may further deposit the accepted author's version on a funder's repository at a funder's request, provided it is not made publicly available until 12 months after publication. 


\title{
From Doing to Performing Phenomenology: Implications and Possibilities
}

\author{
Sigrid Merx
}

(C) Springer Science+Business Media B.V. 2011

\begin{abstract}
This commentary on Kurt Vanhoutte and Nele Wynants's 'Performing phenomenology: negotiating presence in intermedial theatre' focuses on the implications of staging phenomenological research. In my opinion the authors missed an opportunity to stress more what $W$ (Double $U$ ), a performance of CREW has to offer postphenomenology and what it actually means to 'perform' phenomenology. I will not only argue that $W($ Double $U$ ) because of its performative nature offers a reflection on postphenomenology, but also that the performance must be understood as a specific kind of research, conducted simultaneously from a theoretical and aesthetic orientation, leading to a complex interaction between perception and reflection, and offering a valuable, different perspective on postphenomenological research issues. $W($ Double $U)$ in this respect functions as a 'theoretical object', producing a specific kind of embodied knowledge. Finally I will emphasize the possible radical potential in $W$ (Double U), because I do believe that the performance, although it might not lead explicitly to social change, does have an important social and political relevance that the authors do not really delve into.
\end{abstract}

Keywords Staging · Performative orientation - Aesthetic orientation · Politics of perception $\cdot$ Restoring perceptibility

\section{Introduction}

All acts of writing involve decisions on what not to write. Other than overt omissions, those intended left-outs are part of the skill of writing. In the case of writing a commentary things that have not been written are maybe even more fuel for writing than those things that found their way to the text. My commentary has grown out of such a feeling of 'missing'. It all started with missing a specific word.

S. Merx $(\bowtie)$

Theatre, Film and Television Studies, Utrecht University, Utrecht, The Netherlands

e-mail: s.merx@uu.nl 
Let me first express however how happy I am to find an article on theatre in a journal titled Foundations of science. The guest editors meant business when they issued a call for papers that were to 'open up the in-between' (Goeminne and Paredis 2011). They invited interdisciplinary reflections on science, technology and social change. And they succeeded, judging from the variety of articles and the different academic backgrounds their authors are coming from. I wonder however why 'art' didn't make it into the headline of this special issue. If the case study of $W$ (Double $U$ ) proves something it is that especially theatre is able to open op that in-between. So why not reflect on science, technology, art and social change?

The title luckily did not withold Vanhoutte and Wynants (2011) from contributing and 'theatre' did find it's way to the title of their article quite prominently. In their article the authors take the case of $W$ (Double $U$ ) to reflect on the interaction between art, science and technology, however, in their contribution it is the aspect of social change that, so it seems to me, is somewhat missing. Even without being able to offer clear answers, and being most hesitant to relate theatre too easily to bold notions of 'changing the world', it would be interesting at least to ask what could be the possible social and political relevance of this experiment where vision is swapped by means of technology, resulting in disturbing and confusing physical sensations that, as the authors argue, seem to reflect our contemporary ontological condition. In my commentary I will focus on the possible importance and relevance of CREW's artistic practice for both scientific and political praxis; relevance the authors don't deny as far as I can tell, but do not really elaborate on either.

\section{Staging 'Doing Phenomenology'}

To start my argument, I would like to take a look at the title of Vanhoutte and Wynant's article: 'Performing phenomenology: negotiating presence in intermedial theatre' (Vanhoutte and Wynants 2011). It is hard not to see this title as a playful reference to Ihde's well-known phrase: doing phenomenology. Where Ihde used the phrase to call up for a specific style of phenomenology that he coined 'postphenomenology', emphasizing its pragmatic and empirical character, the authors chose these words to describe and discuss the specific performative style of CREW, a multi-disciplinary team of artists and scientists that create performances that experiment with human-machine relationships.

The authors believe that postphenomenology has a lot to offer for the study of theatre, especially those intermedial performances where live performance and technology are fused. They therefore suggest to adopt a postphenomenological attitude to study $W$ (Double $U$ ), their experimental case. I am completely on the authors sides in bringing postphenomenology to the field of intermedial performance analysis, but I would have liked to see that the authors had stressed more explicitly the possibilities of theatre for postphenomenology as well. I agree with Bleeker, who follows Bal, that theatre performances can function as theoretical objects, 'theoretically meaningful statements embodied in the artistic discourse of the theatre'. (Bleeker 2008, p. 8) Theatre by definition implies a process of embodying, moreover, as the authors have mentioned, theatre as a hypermedium has the potential not only to represent, but also to present and therefore render visible and reflect on human-machine relationships. This makes a good case for especially postphenomenology to take up an interest in theatre as a laboratory for its pragmatic, empirical research.

I will argue that what theatre, such as CREW's work, has to offer postphenomenology is an aesthetic orientation (Seel) towards 'doing phenomenology'. Moreover, it is through this aesthetic orientation we can understand how CREW's performances also have a political dimension. I believe that it is precisely the difference between 'doing' and 'per- 
forming' phenomenology that points to the specific relevance of intermedial theatre as live performance for the field of postphenomenology. One could say that performing entails not only the executing but also simultaneously the staging of 'doing'. As an example of empirical research into aspects of presence and spectatorship in a film-based 3D immersive environment $W$ (Double $U$ ) can be understood as a postphenomenological research project and as such is a case of 'doing' phenomenology. However, the fact that this research has taken the shape of a live performance at the same time implies the live staging of this research; in other words the staging of 'doing phenomenology'.

\section{Committed Observers and Reflexive Participants}

One of the effects of staging 'doing phenomenology' in $W$ (Double $U$ ) is that two different orientations towards research are demonstrated. Both CREW's team members and immersants perform the 'role' of researcher, although their research is informed by different intentions. With regard to CREW I would say the 'performative orientation' (Habermas) prevails.

In his article 'Intermediality in Performance and as a Mode of Performativity' Kattenbelt (2010) argues that Habermas' notion of performative orientation implies two complementary perspectives: 'that of a reflexive committed observer and that of a directly involved participant.' (p. 31) On the one hand the performative orientation of CREW is most closely connected with the perspective of the committed observer. The team observes and reflects on the experiment as it unfolds. On the other hand, because of the act of staging, the team is revealed as a participant in the experiment. The team members present themselves both indirectly and directly within the frame of the performance. Indirectly, as they are represented in the world of the immersants by means of the technology they developed and that they use to control — to a certain extent - the virtual world presented to the immersants. Directly, since they put themselves on stage, visible for the audience, working their computers, guiding, and manipulating the immersants. In other words the reality they observe is a reality they helped to create in the first place. Research is revealed here literally as 'making' a case. Moreover, the process of staging makes research visible as an embodied act, a simultaneous being in and looking at the world, and consequently as a continuous balancing between being an observer and a participant.

This balancing act resembles in a way what the authors with regard to the immersants describe as 'the dialectics between a disembodied and an embodied perspective towards the perceived world.' There is however an important difference in orientation. Whereas the performance of CREW can be characterised by its theoretical orientation (making and testing claims) the performance of the immersants stands out because of its 'aesthetic orientation'. (Seel) Kattenbelt argues that the aesthetic orientation can be considered as a specific form of the performative orientation. (p. 31) Following Seel he understands the aesthetic orientation primarily as an interest in perceiving and presenting experience qualities: '[it] concerns an emotionally intensified, affective perception and a reflexive orientation towards one's own subjectivity.' (Idem) In the experimental set-up as created by CREW the immersants present, by means of technology, their (visual) experiences to each other. The perceptual and corporal disturbance that is created as a result of the exchange of vision not only provokes an intensified experience of their own bodies, but also, as the authors show, ignites reflection on their embodied subjectivity.

As investigators of technology, their own bodies and their perceptions, these immersants, although performing from a different orientation, are as much to be understood as researchers 
'doing phenomenology' as CREW's team, producing a specific kind of valuable knowledge, that is not so much knowledge of the objective world, but, as the authors argue, a 'selfknowledge' of the dialectic experience of negotiating different states of being. It is precisely this self-knowledge that also points to the potentially social and political relevance of $W$ (Double U).

\section{Politics of Perception: Restoring Perceptibility}

There is something radical in deliberately seeking a critical awareness of processes of looking. The perceptual clash that occurs as a result of the live swap of the immersants' fields of vision can be considered as a specific aesthetic strategy.

I believe that CREW with $W$ (Double $U$ ) engages in what Rancière calls a 'politics of perception'. A central theme in Rancière's The politics of aesthetics (2004) is the distribution of the sensible, the survey of strategies and power relations that determine what is to be seen in the world and what is made imperceptible. It refers both to forms of inclusion and exclusion.

In $W$ (Double $U$ ) CREW uses and explicitly demonstrates technology as a strategy to control, manipulate, and even distort vision. At the same time however their case shows that within this controlled visual environment the immersants search for ways to restore sight in one way or another and to regain control over their perception. In order to succeed they have to adopt an active attitude, communicating with each other, guiding each other and most importantly, testing and experimenting with the technology. In other words, they are invited to bring themselves and the technology 'into play'. The act of staging allows for such playfulness. Within the secure frame of the performance there is, both for the immersants and CREW's team, time and space to experiment with technology and perception. In this regard $W($ Double $U)$ reveals how science and art, through their experimental attitude, do share a creative potential.

$W$ (Double $U$ ) provokes a new perception and realignment of the body and as such I believe it can contribute to what Buck-Morrs calls 'restoring perceptibility'. In her article 'Aesthetics and Anaesthetics: Walter Benjamin's Artwork Essay Reconsidered' (1992) she claims that new media and technologies can help 'to undo the alienation of the corporeal sensorium'. Buck-Morrs argue that the cognitive system of synaesthesia has turned into a condition of anaesthesia under the infuence of the industrial conditions of modernity, whose goal is no longer to be bodily receptive to external stimuli but to 'numb the organism, to deaden the senses, to repress memory'. In this 'crisis of perception', she argues, it is no longer a question of educating the crude ear to hear music, but of giving back hearing; it is no longer a question of training the eye to see beauty, but of restoring: perceptibility (p. 11).

I argue that performances such as $W$ (Double $U)$, staging and experimenting with human and technology interaction, might have such a restorative potential and can function in a way as a safe, perceptual training ground for our contemporary mediatized society, with all the ontological implications these processes of mediatization bring about. In particular $W$ (Double $U$ ) offers 'training' in how we can be present in the world through vision. Dutch theatre maker Lotte van den Berg who systematically explores perception processes in her performances asks: 
What is looking, and what does it mean to see anything? [...] You can look at something without changing anything, and still be involved. The way you relate to the world doesn't only concern the things you do, but also the way you are present in the world. Once actualizes this presence through the act of perception and the close survey of this perception. (cited in Groot Nibbelink and Merx 2010, p. 226)

$W$ (Double $U$ ) poses the question what it means to see through someone else's eyes. The authors show that paradoxically enough the swap of vision results in a renewed and intensified corporal awareness of one's own vision. Moreover, the performance evokes in the immersants an awareness of their vision as an embodied act, as an active way of being present in and presenting themselves through their vision to the world they live in. And finally the performance installs in the immersants the awareness that they are present in the world with others. $W$ (Double $U$ ) reveals that looking does not occur in a vacuous space, but is in constant interaction with the looking of others. And it is precisely from the point of view of the other that the immersants in this experiment can find themselves back.

The immersants depend on each other for their sight. They have to collaborate in order to create a stable vision for both of them. Not only, as the authors argue, do the immersants tend to unify the divergent ontologies of the 'real' and the 'virtual' to a meaningful experience, as I would like to emphasize they also try to come to an unified understanding of the situation with each other. Looking through each other's eyes simultaneously implies a moving along with the other, striving for a shared definition of the situation, opening oneself up to the other, sharing experiences. $W($ Double $U$ ) is therefore not only, as the authors suggest, about 'negotiating presence' but as much about negotiating co-presence. Following Seel and Kattenbelt I believe that it is only within the context of a presupposed communality in the life experiences of others that we can experience and reflect upon our own subjectivity (Kattenbelt 2010, p. 31).

$W($ Double $U$ ) entails a politics of perception that, although it takes place in a virtual reality within the context of a performance, in the end implies a thorough commitment with and involvement in the world we live in with others.

\section{Conclusion}

As a consequence of the act of staging 'doing phenomenology', perception and reflection are produced live within the frame of the performance. Whereas in most scientific research the perspective of the observer prevails, in the work of CREW perception and reflection go hand in hand. $W$ (Double $U$ ) gives way to a mutual influencing: reflection becomes perceptual and perception becomes reflexive. I believe that it is this simultaneous presence of reflection and perception, this in-between, that allows it to contribute both to scientific and social/political praxis.

\section{References}

Bleeker, M. (2008). Visuality in the theatre. The locus of looking. Houndsmill: Palgrave MacMillan. Goeminne, G., \& Paredis, E. (2011). Opening up the in-between: lhde's postphenomenology and beyond. Foundations of Science, 16(2-3), 101-107.

Groot Nibbelink, L., \& Merx, S. (2010). Presence and perception. Analyzing intermediality in performance. Mapping intermediality in performance (pp. 218-229). Amsterdam: Amsterdam University Press.

Hoens, D. (2011). What is new about new media? Foundations of Science. doi:10.1007/s10699-011-9256-5. 
Kattenbelt, C. (2010). Intermediality in performance and as a mode of performativity. Mapping intermediality in performance (pp. 29-37). Amsterdam: Amsterdam University Press.

Rancière, J. (2004). The politics of aesthetics. English translation and introduction by Gabriel Rockhill. London and New York: Continuum.

Vanhoutte, K., \& Wynants, N. (2011). Performing phenomenology: Negotiating presence in intermedial theatre. Foundations of Science, 16(2-3), 275-284.

\section{Author Biography}

Sigrid Merx (1975) is an Assistant Professor Theatre Studies at Utrecht University where she teaches in the BA programme Theater, Film and Television Studies and in the MA programme Theater Studies. Previously she was a middle school drama teacher and was active as a playwright, writing coach and dramaturge in several youth theatre productions. June 2009 she finished her Ph.D. thesis on video and the (re)presentation of time in the Proust cycle, a series of four performances by Flemish director Guy Cassiers. In her current teaching she focuses on theatre and performance in the context of other media and performance. Her research interests are: theatre and engagement, theatre and ethics, and theatricality in politics and political art. Sigrid is also member of the board for the Domein voor Kunstkritiek (Institute for Art Criticism) and is still active as a freelance writer and dramaturge, especially in community art projects. 